\title{
EBI-3 Chain of IL-35 Along With TGF- $\beta$ Synergistically Regulate Anti-leishmanial Immunity
}

\section{Mohammad Asad ${ }^{\dagger}$, Abdus Sabur, Mohammad Shadab ${ }^{\dagger}$, Sonali Das, Mohd. Kamran, Nicky Didwania and Nahid Ali*}

Infectious Diseases and Immunology Division, Council of Scientific and Industrial Research-Indian Institute of Chemical Biology (CSIR-IICB), Kolkata, India

OPEN ACCESS

Edited by:

Heinrich Korner

University of Tasmania, Australia

Reviewed by:

Werner Solbach,

Universität zu Lübeck, Germany

Catherine Margaret Miller,

James Cook University, Australia

*Correspondence:

Nahid Ali

nali@iicb.res.in

tPresent address:

Mohammad Asad,

School of Medicine, Department of Dermatology, University of Alabama at

Birmingham, Birmingham, AL, United States

Mohammad Shadab,

Department of Pediatrics, University of Rochester Medical Center School of Medicine and Dentistry, Rochester, NY, United States

Specialty section: This article was submitted to Microbial Immunology, a section of the journal

Frontiers in Immunology

Received: 26 July 2018 Accepted: 08 March 2019 Published: 12 April 2019

Citation:

Asad M, Sabur A, Shadab M, Das S, Kamran M, Didwania N and Ali N (2019) EBI-3 Chain of IL-35 Along With TGF- $\beta$ Synergistically Regulate

Anti-leishmanial Immunity.

Front. Immunol. 10:616. doi: 10.3389/fimmu.2019.00616
Immunosuppression is a characteristic feature of chronic leishmaniasis. The dynamicity and the functional cross talks of host immune responses during Leishmania infection are still not clearly understood. Here we explored the functional aspects of accumulation of immune suppressive cellular and cytokine milieu during the progression of murine visceral leishmaniasis. In addition to IL-10 and TGF- $\beta$, investigation on the responses of different subunit chains of IL-12 family revealed a progressive elevation of EBI-3 and p35 chains of IL-35 with Leishmania donovani infection in BALB/c mice. The expansion of CD25 and FoxP3 positive T cells is associated with loss of IFN- $\gamma$ and TNF- $\alpha$ response in advanced disease. Ex-vivo and in vivo neutralization of TGF- $\beta$ and EBI-3 suggests a synergism in suppression of host anti-leishmanial immunity. The down-regulation of EBI-3 and TGF- $\beta$ is crucial for re-activation of JAK-STAT pathway for induction as well as restoration of protective immunity against $L$. donovani infection.

Keywords: regulatory $\mathrm{T}$ cells, Leishmania, immune response, interleukin-35, transforming growth factor beta, immune suppression

\section{INTRODUCTION}

Maintenance of immunological self-tolerance and homeostasis by restraining disproportionate and detrimental immune responses is primarily mediated by regulatory cytokine secreting lymphocytes (1). Conversely, expansion of regulatory cellular and cytokine milieu may lead to compromised immunity against certain infections such as Brucella, HIV, helminthes, and Mycobacteruim tuberculosis including antitumor host immune responses (2-5). However, the correlation between effector and regulatory cell populations especially in terms of sensing and secretion of cytokines during diseased condition is still not well understood (6).

Visceral leishmaniasis (VL) is a potentially lethal disease caused by parasitisation of cellular components of innate immune system by Leishmania donovani/Leishmania infantum (7). A dysfunctional cell mediated immune response is one of the characteristic features of chronic VL $(8,9)$. Several studies have suggested the role of IL-10 and TGF- $\beta$ in subversion of proinflammatory response in active $\mathrm{VL}(10,11)$. Despite crucial evidences of the role of these cytokines in augmenting VL pathology, the mode of action of these immunosuppressive cytokines is not clearly understood (12). Apart from IL-10 and TGF- $\beta$, the role of other immunosuppressive cytokines in VL is yet to be established. IL-35 has been reported for its immunosuppressive activity in autoimmunity and infectious diseases (13-15). IL-35 is a heterodimeric cytokine with two polypeptides " $\alpha$ " and " $\beta$ " chains. These polypeptides may participate in the construction of two or more cytokines for 
example the $\alpha$-chain, p35, is shared by IL-12 and IL-35, and the $\beta$-chain EBI-3 is shared by IL-27 and IL-35 (15). The roles of the subunit chains of IL-35 in immuno-regulation during VL are not known.

In the present study, we show the dynamicity of different subsets of $\mathrm{CD} 4^{+} \mathrm{T}$ cells at different stages of $L$. donovani infection of $\mathrm{BALB} / \mathrm{c}$ mice and their contribution to different cytokine responses. In consistence to the previous reports of IL-10 and TGF- $\beta$, we additionally report the effect of the subunit chains of IL-35. We demonstrated the mechanistic action of TGF- $\beta$ and EBI-3 in inhibition of $\mathrm{CD}^{+}{ }^{+} \mathrm{T}$ cell-mediated Th1 response and its consequent effect on VL pathogenesis.

\section{MATERIALS AND METHODS}

\section{Animals and Parasites}

$\mathrm{BALB} / \mathrm{c}$ mice (6-8 weeks old), bred in the Institute's animal house facility, were infected with $L$. donovani strain AG83 (MHOM/IN/1983/AG83) (ATCC No. ATCC ${ }^{\circledR}$ PRA-413 ${ }^{\mathrm{TM}}$ ), originally isolated from an Indian kala-azar patient, was maintained by serial passage in hamsters.

\section{Determination of Hepatic and Splenic Parasite Burden}

Spleens from infected hamsters were aseptically removed and the splenocytes were cultured in Schneiders' insect medium containing $10 \% \mathrm{FBS}$ and $1 \%$ penicillin streptomycin to allow the infected amastigotes to transform into promastigotes at $22^{\circ} \mathrm{C}$ for 2 weeks. The freshly transformed promastigotes were then cultured in M199 medium containing 10\% FBS and 1\% penicillin streptomycin and passaged in fresh medium maintaining a parasites density of $10^{6}$ promastigotes $/ \mathrm{ml}$. The promastigotes of $2 \mathrm{nd}$ or $3 \mathrm{rd}$ passage were washed several times in $0.02 \mathrm{M}$ phosphate-buffered saline (PBS) of $\mathrm{pH} 7.2$ and observed in the microscope before injecting $\left(2.5 \times 10^{7}\right.$ cells $\left./ 0.2 \mathrm{ml} \mathrm{PBS}\right)$ i.v., into $\mathrm{BALB} / \mathrm{c}$ mice as described previously (16). At different mentioned time points of infection, spleen and liver were removed from the mice and multiple impression smears were prepared and stained with Giemsa. Organ parasite burdens expressed as Leishman-Donovan units (LDU) were calculated as the number of parasites per 1,000 nucleated cells $\times$ organ weight (mg). To determine whether the spleen and liver contained live parasites, the parasite burden was quantified in these tissues by Limiting Dilution Assay (LDA) as previously described (1719). Briefly, a weighed small piece of spleen or liver from experimental mice was first homogenized in Schneider's medium supplemented with $10 \%$ FCS, and then diluted with the same medium to a final concentration of $1 \mathrm{mg} / \mathrm{ml}$. Five-fold serial dilution of the homogenized tissue suspensions were plated in 96-well plates and incubated at $22^{\circ} \mathrm{C}$ for $2-3$ weeks. Wells were examined for viable and motile promastigotes after 15 days, and the reciprocal of the highest dilution positive for parasites was considered as the parasite concentration per milligram of tissue. The total organ parasite burden was calculated using the weight of the respective organs.

\section{Cell Proliferation and Cytokine Assays}

For cell proliferation and cytokine assays, single cell suspensions of infected and control mice splenocytes were prepared in RPMI 1640 supplemented with $10 \% \mathrm{FBS}, 100 \mathrm{U} / \mathrm{ml}$ penicillin G sodium, $100 \mu \mathrm{g} / \mathrm{ml}$ streptomycin sulfate and $50 \mu \mathrm{M} \beta$-mercaptoethanol (complete medium). RBCs were removed by lysis with $0.14 \mathrm{M}$ Tris-buffered $\mathrm{NH}_{4} \mathrm{Cl}$. The remaining cells were washed twice with culture medium and viable mononuclear cells were counted in a haemocytometer by Trypan blue exclusion method. The cells were then cultured in a 96 well flat bottom plate at a density of $2 \times 10^{5}$ cells/well in a final volume of $200 \mu \mathrm{l}$ complete medium and stimulated with Leishmanial-antigen $(\mathrm{LAg})(10 \mu \mathrm{g} / \mathrm{ml})$. The cells were incubated for $72 \mathrm{~h}$ at $37^{\circ} \mathrm{C}$ in a humified chamber containing $5 \% \mathrm{CO}_{2}$ as described earlier with little modifications (20). For cytokine analysis, culture supernatants were collected after $72 \mathrm{~h}$ of incubation and the concentration of IL-12p40, TNF- $\alpha$, IFN- $\gamma$, IL-12p35, IL-4, IL-10, TGF- $\beta$, EBI-3 (USCN Life Science), and IL-27p28 (eBioscience) were quantified by ELISA in accordance with the manufacturer's instructions. All the kits were purchased from Beckton Dickinson (BD Pharmingen), unless mentioned. Sera were collected from various groups of mice, as required and cytokine ELISA was performed according to manufacturers' instructions.

\section{Flow Cytometry}

Splenocytes from different groups of experimental and healthy mice were stimulated for $12 \mathrm{~h}$ with $\mathrm{LAg}(10 \mu \mathrm{g} / \mathrm{ml})$ as described earlier (20). Brefeldin A $(10 \mu \mathrm{g} / \mathrm{ml})$ was added to the cultures $2 \mathrm{~h}$ before harvest. The cells were then washed in FACS buffer (0.02 M PBS, $1 \%$ FBS, and $0.01 \%$ sodium azide) and stained with fluorescent conjugated surface markers $(0.2 \mu \mathrm{g} / \mathrm{sample})$ for CD3 (APC-Cy7), CD4 (PE-Cy7 or BUV395), CD8 (Percp-Cy5.5), and CD25 (FITC). Subsequently, cells were permeabilized with FACS permeabilizing solution and washed in FACS buffer containing $0.1 \%$ saponin. The cells were then stained for intracellular marker, FoxP3 (Alexa Fluor 647) and cytokines, IL-4 (PECF594), IL-10 (BV711), TGF- $\beta$ (eFluor710, eBioscience or BV421), EBI3 (PE, BioLegends), TNF- $\alpha$ (BV650), and IFN- $\gamma$ (Pacific blue). All the kits were purchased from BD Pharmingen, unless mentioned. Data were acquired by LSR Fortessa (BD Biosciences) and analyzed through FlowJo software (TreeStar). Fluorescence Minus One (FMO) for cytokine or rare cell populations was used for elimination of false positive signal in multiparametric study.

\section{Co-culture of CD4 ${ }^{+} \mathrm{CD}^{-} 5^{-}$and $\mathrm{CD}^{+}{ }^{+} \mathrm{CD}^{2} 5^{+} \mathrm{T}$ Cells}

Four months infected BALB/c mice were sacrificed and spleen were removed aseptically. $\mathrm{CD} 4{ }^{+} \mathrm{CD} 25^{-}$and $\mathrm{CD} 4{ }^{+} \mathrm{CD} 25^{+}$ $\mathrm{T}$ cells were enriched by magnetic sorting according to manufacturer's protocol using lymphocyte enrichment kits (BD Pharmingen) (21). CD $4^{+} \mathrm{CD} 25^{-} \mathrm{T}$ cells, labeled with carboxyfluorescein succinimidyl ester (CFSE) (Molecular Probes) were stimulated with anti-CD3 $(10 \mu \mathrm{g} / \mathrm{ml})$ and anti-CD28 $(10 \mu \mathrm{g} / \mathrm{ml})$ in 96-well plates and cultured with $\mathrm{CD}^{+}{ }^{+} \mathrm{CD} 25^{+} \mathrm{T}$ cells in various ratios (keeping total cells numbers $5 \times 10^{5} /$ well) (13). After $96 \mathrm{~h}$ cells were collected for $\mathrm{CFSE}$ based $\mathrm{CD} 4{ }^{+} \mathrm{CD} 25^{-}$proliferation assay through 
flow cytometry. In few experiments, neutralizing mAbs (BioLegend) against CD25, IL-27(p28), IL-10, TGF- $\beta$ and EBI-3 were added $(20 \mu \mathrm{g} / \mathrm{ml}$ each $)$ in the co-culture of $\mathrm{CD} 4{ }^{+} \mathrm{CD} 25^{-} \mathrm{T}$ cells and $\mathrm{CD} 4{ }^{+} \mathrm{CD} 25^{+} \mathrm{T}$ cells (1:1 ratio) and post $96 \mathrm{~h}$, the culture supernatants were collected for cytokine ELISA.

\section{In vivo Neutralization of TGF- $\beta$ and IL-35}

TGF- $\beta$ and IL-35 (EBI-3) were neutralized by mAbs (BioLegend) as reported $(22,23)$ with little modifications. Briefly, EBI-3 and TGF- $\beta$ antibodies were administered in $200 \mu \mathrm{l}$ PBS solution $(0.02 \mathrm{M}, p \mathrm{H} 7.2)$ into the peritoneum of the BALB/c mice either individually (200 $\mu \mathrm{g} /$ mice/antibody) or in combination (100 $\mu \mathrm{g} / \mathrm{mice} /$ antibody) $24 \mathrm{~h}$ prior to infection and subsequently each week doses until sacrificed post infection. Separate groups of isotype control $(200 \mu \mathrm{g} /$ mice IgG cocktail) and $\alpha$-CD25 antibodies $(200 \mu \mathrm{g} /$ mice $)$ were also included.

\section{Western Blot}

Splenic cells were processed for cell lysate preparation, as described earlier (24). Firstly cells were lysed in cell lysis buffer (1X TBS containing 1\% TritonX-100, $1 \mathrm{mM}$ DTT, protease and phosphatase inhibitor cocktail), and the protein concentration in the cleared supernatants obtained after centrifuging at $1000 \mathrm{~g}$ were estimated using Lowry's method. The cell lysates were then resolved by $10-12 \%$ SDS-PAGE and transferred to nitrocellulose membrane (Millipore). The membranes were then blocked with 5\% BSA in TBS for $1 \mathrm{~h}$ at room temperature and probed with primary $\mathrm{Ab}$ diluted in 5\% BSA in TBS by incubating at room temperature for $2 \mathrm{~h}$. After washing the membranes with TBST (Tween $0.5 \%)$ thrice for $5 \mathrm{~min}$ each, they were again probed with secondary antibody in TBST for $1 \mathrm{~h}$. The membranes were then washed again three times each with TBST and finally detected by chemiluminescence.

\section{Statistical Analysis}

All data comparisons were tested for significance by One-way analysis of variance (ANOVA) and Tukey's multiple comparisons using Graph Pad Prism version 5.0 (GraphPad Software, v. 5.0, (or Student's T test were employed were ever indicated) San Diego, CA). Results with $p<0.05$ were considered to be statistically significant.

\section{RESULTS}

\section{Progression of $L$. donovani Infection and Associated Cytokine Responses in BALB/c Mice}

Sets of BALB/c mice infected at different time points with L. donovani including uninfected controls were sacrificed to evaluate organomegaly, parasite burden and infection induced immunomodulations. Progressive increase in weight of liver and spleen was apparent during the course of infection (Figure 1A). No apparent organomegaly were observed in age matched control groups. Infection induced hepato-splenomegaly was directly correlated to the parasite burdens in the respective organs as estimated by LDU as well as LDA methods (Figures 1B,C). A non-resolving infective pattern was observed until 4 months of infection (liver LDU $=2558 \pm 374.9$; $\log _{10}$ values of $\mathrm{LDA}=11.94$ \pm 0.36 and spleen $\mathrm{LDU}=949.9 \pm 123$; $\log _{10}$ values of $\mathrm{LDA}=$ $8.84 \pm 0.68)$. Cytokine responses in infected mice were assayed from culture supernatants of leishmanial-antigen stimulated splenocyte cultures. Like natural infection, a gradual surge in the levels of IL-4, IL-10, and TGF- $\beta$ were observed, while the levels of IFN- $\gamma$ and TNF- $\alpha$ increased gradually at early infection but were reduced to basal level at chronic infection (Figure 1D). Among various Chains of IL-12 family, the expressions of IL12 (p35) and EBI-3 were progressively elevated with infection, whereas, the expression of IL-27 (p28) chain was found unaltered (Figure 1E). Besides, IL-12 the expression of IL-12 (p40) chain was down-regulated at chronic infection.

\section{Immunophenotyping of Cytokine Producing CD4 ${ }^{+} \mathrm{T}$ Cells in Infected Mice}

Splenocytes obtained from naïve and infected mice were immuno-phenotypically characterized for cytokine producing $\mathrm{CD}^{+}{ }^{+} \mathrm{T}$ by flowcytometry. $\mathrm{CD} 4{ }^{+} \mathrm{T}$ cells were gated from $\mathrm{CD} 3^{+}$ single cell population of splenic lymphocytes (Figure 2A). $\mathrm{CD}^{+}$ $\mathrm{T}$ cells were studied for the proportion of $\mathrm{CD} 4^{+} \mathrm{CD} 25^{+}$and $\mathrm{CD}^{+}{ }^{+} \mathrm{FoxP}^{+}$and combination of both. The phenotypically characterized $\mathrm{CD}_{4}^{+} \mathrm{T}$ cell populations were analyzed for IFN$\gamma^{+}, \mathrm{TNF}-\alpha^{+}, \mathrm{IL}-10^{+}, \mathrm{TGF}-\beta^{+}$, and EBI- $3^{+}$T cells. Fluorescence Minus One (FMO) controls were used to rule out false positive populations. The study reveals that the percentage of $\mathrm{CD} 4^{+} \mathrm{CD} 25^{+}$and $\mathrm{CD}^{+}{ }^{+} \mathrm{FoxP}^{+} \mathrm{T}$ cells were progressively enhanced until 4 months of infection compared to control naïve mice (Figure 2A). Analysis of cytokine secretion from early (1 month) infected CD4 T cells reveals an enhanced population of IFN- $\gamma+$, TNF- $\alpha^{+}, \mathrm{IL}-10^{+}, \mathrm{TGF}-\beta^{+}$, and EBI- $3^{+}$T cells compared to uninfected controls (Figures 2B,C). CD4 ${ }^{+} \mathrm{T}$ cells from late (4 months) infected mice show a diminished population of IFN- $\gamma+$, TNF- $\alpha^{+}$as compared to early infected CD4 ${ }^{+}$T cell populations, while the IL- $10^{+}, \mathrm{TGF}-\beta^{+}$, and EBI- $3^{+}$T cells show proportionate surge with disease progression (Figures $2 B, C$ ). The study further reveals that while production IFN- $\gamma$ and TNF$\alpha$ are dominantly restricted to $\mathrm{CD} 4{ }^{+} \mathrm{FoxP}^{-}$and $\mathrm{CD} 4{ }^{+} \mathrm{CD} 25^{-}$ $\mathrm{T}$ cells, the sources of IL-10, TGF- $\beta$, and EBI-3 are from both positive and negative populations of FoxP3 and CD25 (Figures 2B-E).

\section{Increased Proportion of CD4 ${ }^{+} \mathrm{CD}^{2} 5^{+} \mathrm{T}$ Cells ex vivo Leads to Loss of Cell Proliferation and Induction of Regulatory Cytokines}

To evaluate how $\mathrm{CD}^{+}$cells and their cytokine responses are associated with the disease progression, splenic $\mathrm{CD} 4^{+} \mathrm{CD} 25^{-}$ and $\mathrm{CD} 4{ }^{+} \mathrm{CD} 25^{+} \mathrm{T}$ cells of 4 months infected mice were enriched (Figure 3A). Co-cultures of $\mathrm{CD} 4^{+} \mathrm{CD} 25^{-} \mathrm{T}$ cells with $\mathrm{CD} 4{ }^{+} \mathrm{CD} 25^{+} \mathrm{T}$ in various proportions in presence of the anti-CD3 and anti-CD28 stimulation were assayed for CFSE labeled cell proliferation as well as cytokine responses in culture supernatants. A significant loss in the cell proliferative responses 


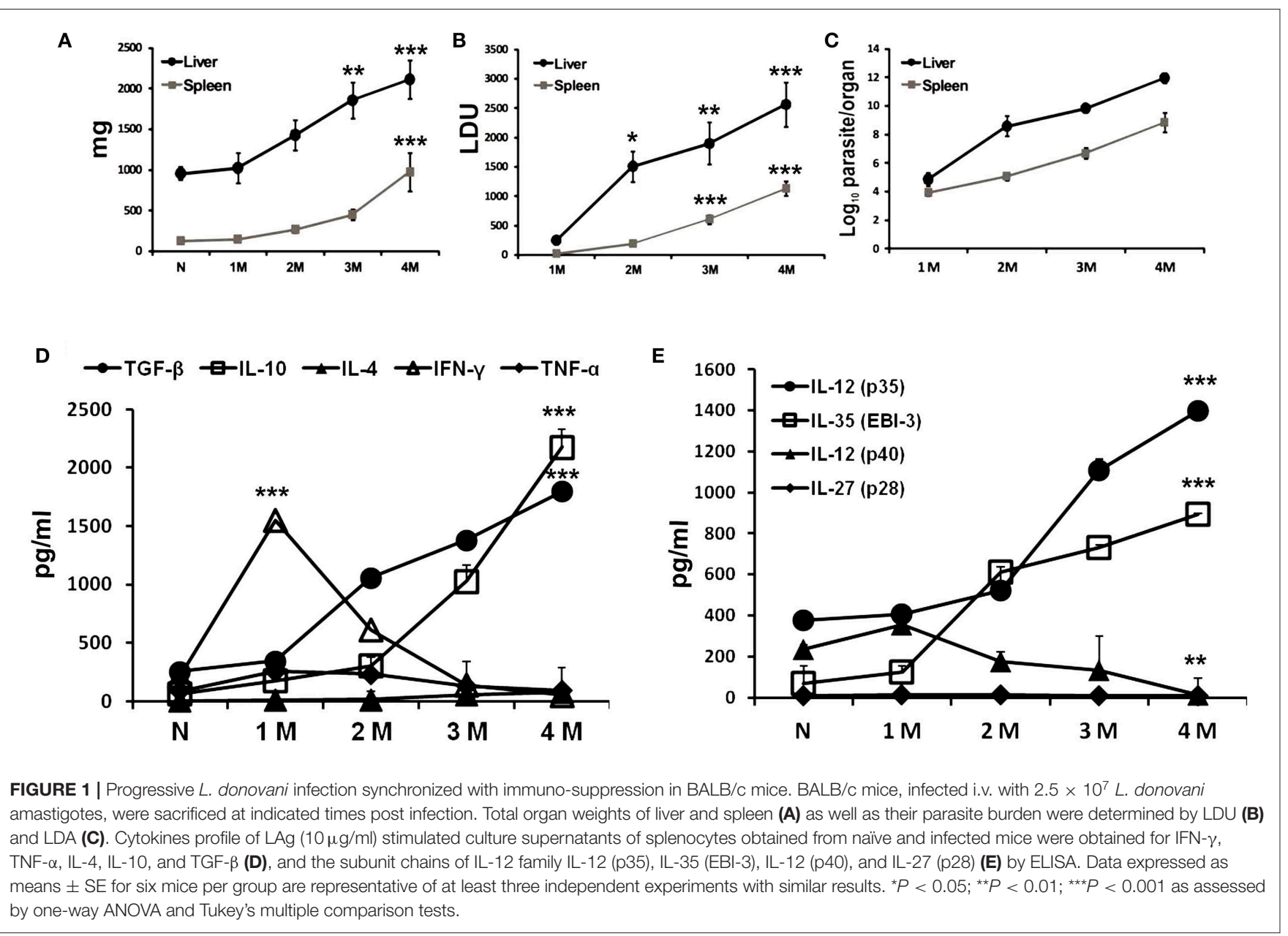

were observed with increasing proportions of $\mathrm{CD} 4^{+} \mathrm{CD} 25^{+}$ $\mathrm{T}$ cells (Figure 3B). At equal concentration of $\mathrm{CD} 4^{+} \mathrm{CD} 25^{-}$ and $\mathrm{CD} 4{ }^{+} \mathrm{CD} 25^{+} \mathrm{T}$ cells (1:1 ratio), $\mathrm{T}$ cell proliferation was suppressed to $\sim 12 \%$. Study of the cytokine response in the co-culture supernatants showed that IL-10, TGF- $\beta$ and EBI3 increased while IFN- $\gamma$ and TNF- $\alpha$ levels decreased with the increasing $\mathrm{CD} 4{ }^{+} \mathrm{CD} 25^{+} \mathrm{T}$ cells (Figures 3C,D). Moreover, IL10 , TGF- $\beta$, and EBI-3 secretion was found to be elevated with the increase in $\mathrm{CD} 4{ }^{+} \mathrm{CD} 25^{+} \mathrm{T}$ cells in co-culture. However, there was unnoticeable deflection in the levels of IL- 4 at various ratios of $\mathrm{CD} 4{ }^{+} \mathrm{CD} 25^{-}$and $\mathrm{CD} 4{ }^{+} \mathrm{CD} 25^{+}$ $\mathrm{T}$ cells.

\section{Neutralization of Regulatory Cytokines ex vivo Restores Cell Proliferation and Proinflammatory Cytokine Response}

The co-cultures of $\mathrm{CD} 4{ }^{+} \mathrm{CD} 25^{-}$and $\mathrm{CD} 4{ }^{+} \mathrm{CD} 25^{+} \mathrm{T}$ cells were treated with neutralizing monoclonal antibodies (mAbs) against CD25, IL-27 (p28), IL-10, TGF- $\beta$, and EBI-3 either singly or in indicated combinations. Neutralization with $\alpha \mathrm{CD} 25$ antibodies in the co-culture of $\mathrm{CD} 4{ }^{+} \mathrm{CD} 25^{+}$and $\mathrm{CD} 4{ }^{+} \mathrm{CD} 25^{-}$ $\mathrm{T}$ cells from infected mice leads to restoration of cellular proliferation (Figure 4A). Administration of $\alpha$ IL-10, $\alpha$ EBI-3 or $\alpha$ TGF- $\beta$ resulted in partial gain in cell proliferation as compared to IgG controls. Moreover, there was no supplementary effect of adding various combinations of $\alpha$ IL-27 (p28), $\alpha$ IL-10, and $\alpha$ TGF- $\beta$. Interestingly, neutralization of EBI-3 either alone or in combination with TGF- $\beta$ show proportionate restoration of cell proliferation in the stimulated co-cultures.

Similar to proliferative responses, neutralization with $\alpha$ IL-10, $\alpha$ EBI-3, or $\alpha$ TGF- $\beta$ leads to partial but significant restoration of IFN- $\gamma$ and TNF- $\alpha$ level in the stimulated co-culture (Figures 4B,C). Neutralization of IL-27 (p28) was apparently ineffective. Among the combined neutralization of various cytokines, administration of $\alpha$ EBI- 3 along with $\alpha$ TGF- $\beta$ resulted in the most effective boost of IFN- $\gamma$ and TNF- $\alpha$ response ( $p$ $<0.001)$, followed by treatment of $\alpha$ EBI-3 along with $\alpha$ IL$10(p<0.01)$.

Effects of neutralization of CD25, IL-10, TGF- $\beta$, EBI-3, and IL-27 (p28) on disease promoting cytokine response were also examined. While homologous suppression following neutralization was observed for all the cytokines, cross regulation of cytokine response could be observed for TGF- $\beta$ and EBI-3 neutralization on IL-10 production (Figures 4D-F). Production 

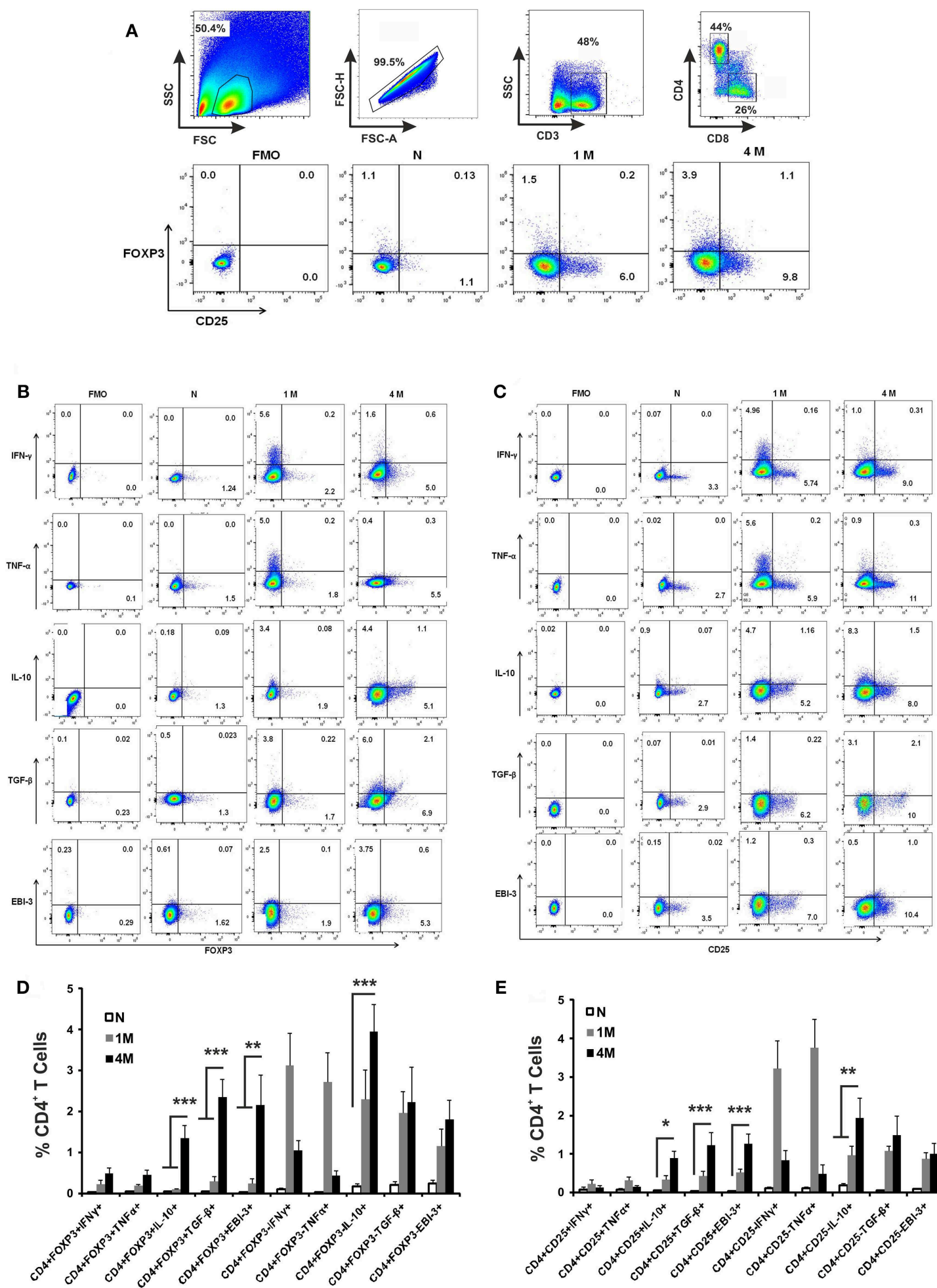

E

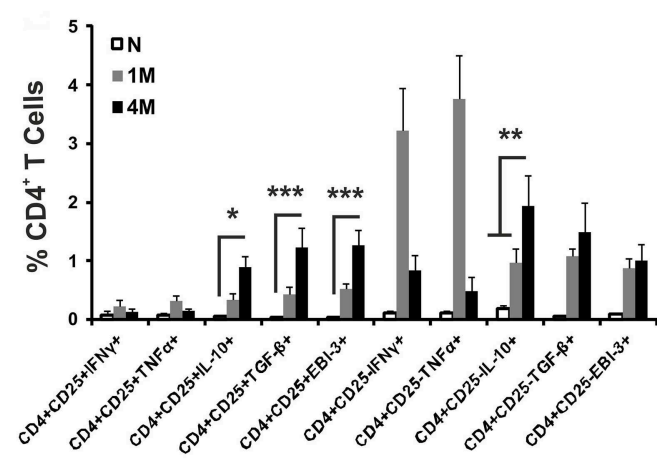

FIGURE 2 | Role of CD4 ${ }^{+}$T cell subsets in cytokine production during L. donovani infection. Infected and control mice splenocytes were stimulated with Leishmanial membrane antigens $(\mathrm{LAg})(10 \mu \mathrm{g} / \mathrm{ml})$ overnight and then cells were processed for flow cytometric studies. CD3 ${ }^{+} \mathrm{T}$ cells were gated from single cell population of splenic lymphocytes, followed by CD4 and CD8 cells (A). Subsequently, sub-sets of CD4 cells were gated based on Fluorescence Minus two controls for the identification of IFN- $\gamma$, TNF- $\alpha$, IL-10, TGF- $\beta$ and EBI-3 positive cells among CD4 ${ }^{+}$Foxp3 ${ }^{+}$(B) as well as CD4 ${ }^{+}$CD25 $5^{+}$(C) as representative dot plots. Data are

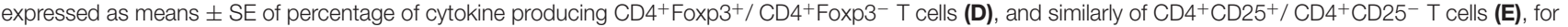
six mice per group with three experimental repeats. Student's $T$-tests were applied to compare the differences in percentage proportion of cytokine producing cells as compared to uninfected controls. ${ }^{\star} P<0.05 ;{ }^{\star \star} P<0.01 ;{ }^{\star \star \star} P<0.001$. 

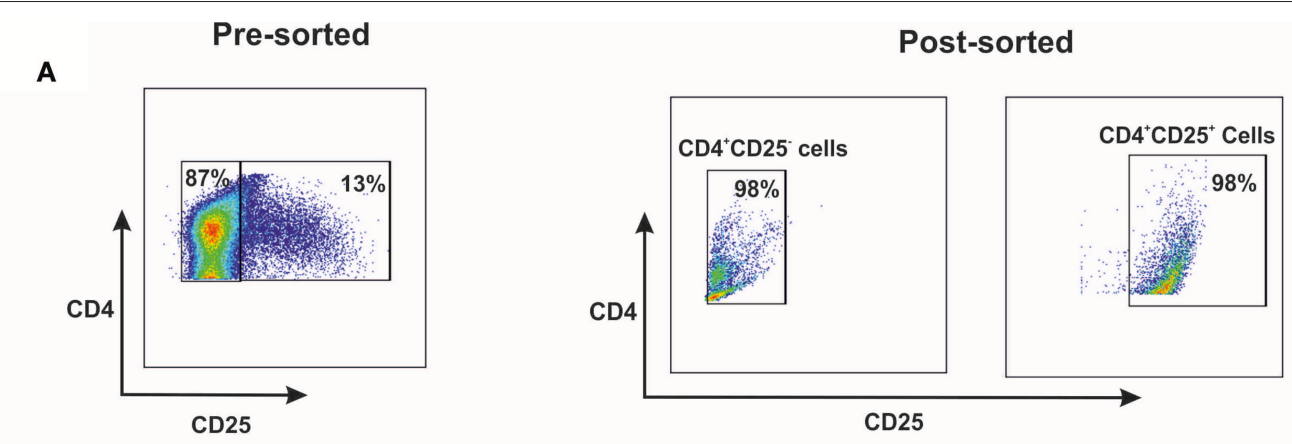

B

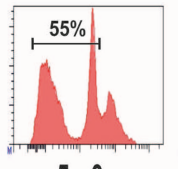

$5: 0$

CD4 ${ }^{+}$CD25 T Cells Proliferation (CFSE)
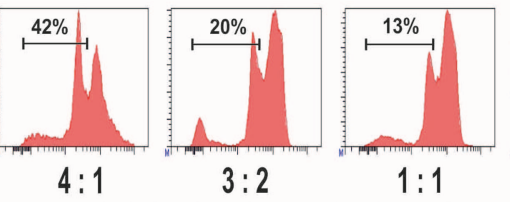

$1: 1$
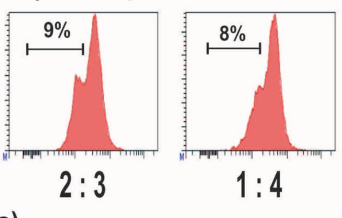

(CD4 CD25T Cells : CD4 ${ }^{+}$CD25 ${ }^{+}$Tregs)

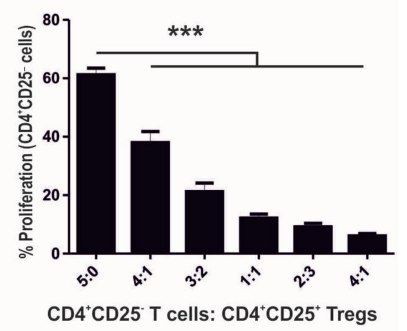

C

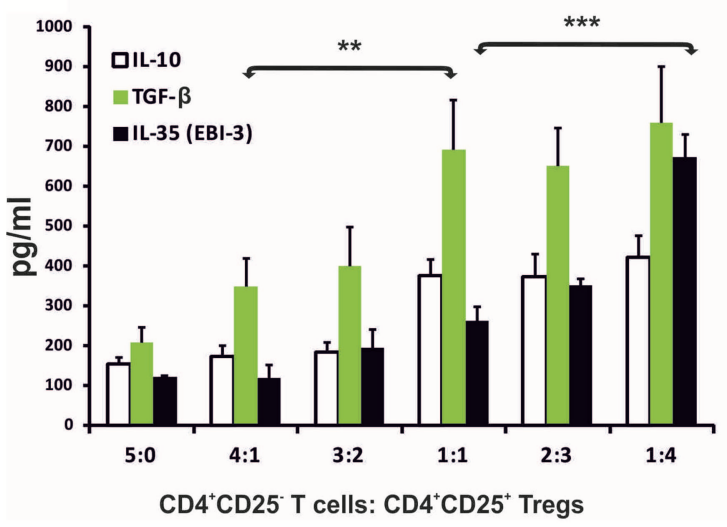

D

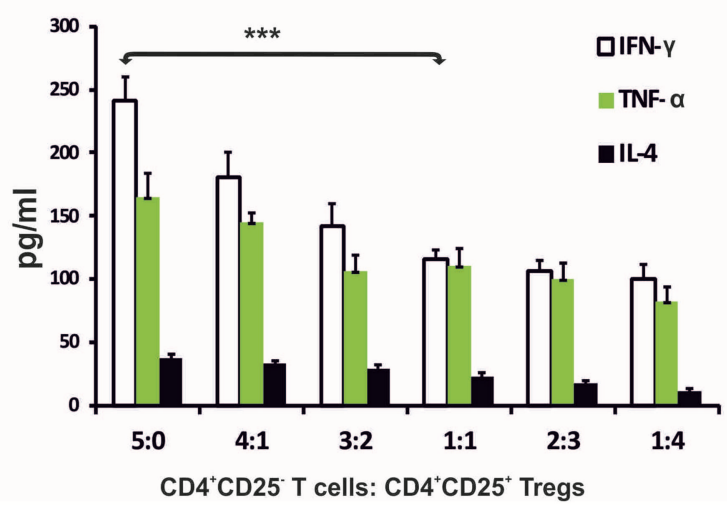

FIGURE 3 | CD4 ${ }^{+} \mathrm{CD} 25^{+} \mathrm{T}$ cells suppressed protective immune response when co-cultured with $\mathrm{CD} 4^{+} \mathrm{CD} 25^{-} \mathrm{T}$ cells. Splenic $\mathrm{CD} 4^{+} \mathrm{CD} 25^{-} \mathrm{T}$ cells $($ labeled with CFSE) and $\mathrm{CD}^{+}{ }^{+} \mathrm{CD} 25^{+}$T cells, were enriched through magnetic sorting from 4 months infected mice (A), were stimulated with anti-CD3 and anti-CD28 and co-cultured in $96 \mathrm{U}$ bottom plate at various indicated ratios. After $96 \mathrm{~h}$ cells were collected for CFSE based CD4 ${ }^{+} \mathrm{CD} 25^{-}$proliferation assay through flow cytometry. Histograms and graph show percent proliferation of CD4+CD25- cells co-cultured with CD4+CD25+ T at various ratios (B). Supernatants of the co-culture were used for cytokine profiling (C,D). Data expressed as means \pm SE for at least five mice per group are representative of three independent experiments with similar results. ${ }^{\star \star} P<0.01 ;{ }^{\star \star \star} P<0.001$ as assessed by one-way ANOVA and Tukey's multiple comparison tests.

of TGF- $\beta$ was regulated by neutralization of EBI-3 and vice versa (Figures 4D-F).

\section{Administration of $\alpha \mathrm{EBI}-3$ Along With $\alpha$ TGF- $\beta$ in the Infected Mice Boosted Host Protective Response Concurrent With a Decline in the Disease Promoting Cytokines}

For investigation of the involvement of EBI-3 and TGF- $\beta$ with the disease progression, monoclonal $\alpha$ EBI- 3 and $\alpha$ TGF- $\beta$ antibodies were administered into the peritoneal cavity of the mice either individually or in combination. The first dose was administered
$24 \mathrm{~h}$ prior Leishmania infection. Subsequent doses were given weekly until the mice were sacrificed. One group of infected mice was also administered with the isotype control (IgG) and another group was treated with $\alpha \mathrm{CD} 25$ antibodies. After 3 months of infection, mice were sacrificed and LAg stimulated splenocytes were cultured for immunophenotyping and cytokine response. IFN- $\gamma$ and TNF- $\alpha$ producing cells are found to be low in control ( $\mathrm{IgG})$ treated mice $(\sim 1$ and $0.5 \%$, respectively), as compared to $\alpha$ TGF- $\beta$ treated $(\sim 2-3 \%)$ and $\alpha$ EBI-3 $(\sim 4-$ $5 \%$ ) treated group in mice (Figures 5A,B). Administration of $\alpha$ EBI-3 in combination with $\alpha$ TGF- $\beta$ increased the IFN$\gamma$ and TNF- $\alpha$ producing cells significantly $(\sim 7.5$ and $6 \%$, respectively), compared to controls. There was no prominent 


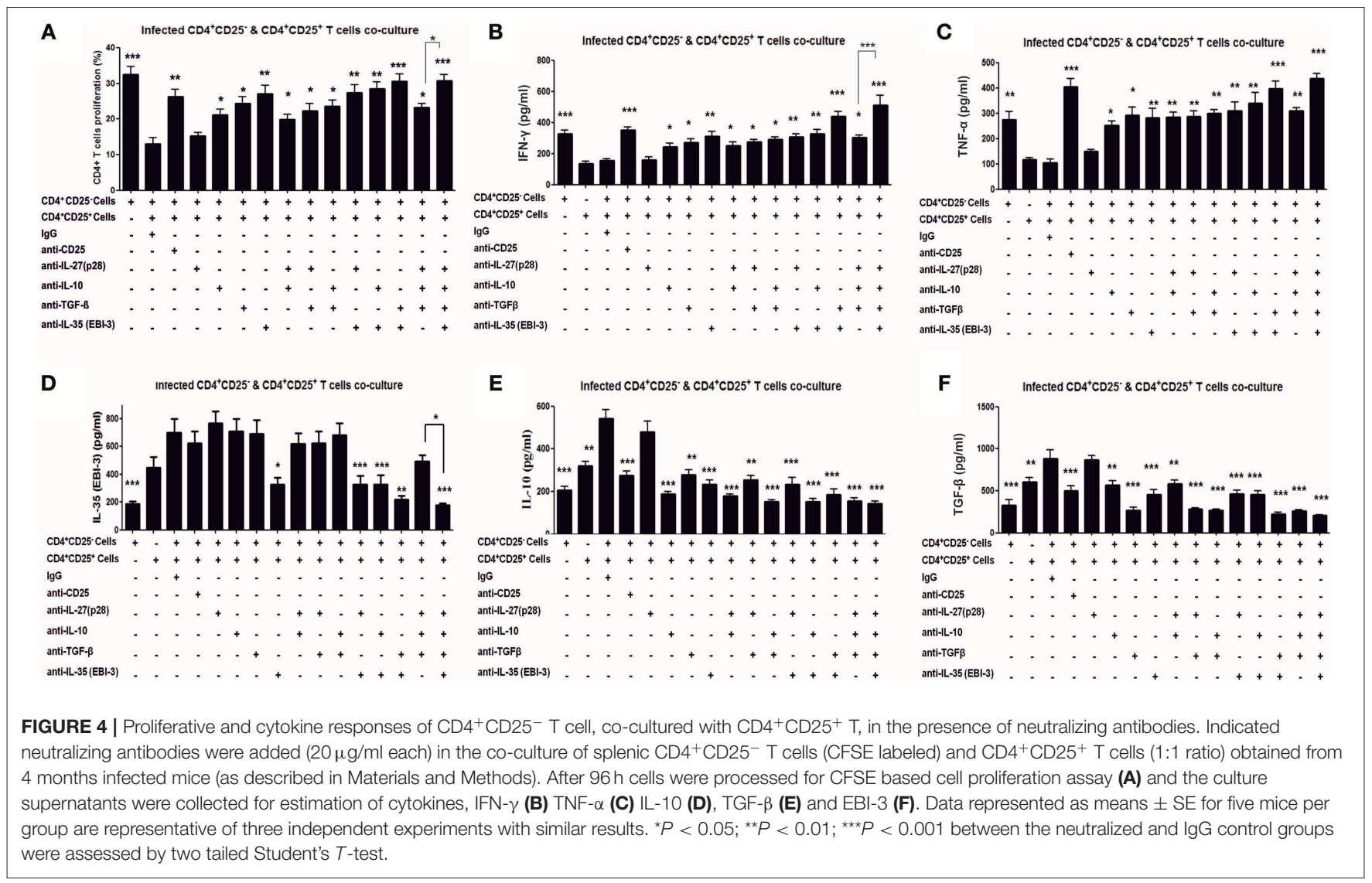

difference in IL- 4 producing CD 4 cells post $\alpha \mathrm{CD} 25$ or $\alpha \mathrm{TGF}-\beta$ treatments (Figure 5C).

We estimated various cytokines from the culture supernatants of splenocytes of $\alpha \mathrm{EBI}-3, \alpha \mathrm{TGF}-\beta$, and $\alpha \mathrm{EBI}-3$ mAbs treated mice through Cytometic Bead Assay (CBA). We found that infected mice treated with IgG produced low amounts of IL12 (p40), IFN- $\gamma$, and TNF- $\alpha$, while the mice treated with $\alpha$ EBI- 3 or $\alpha$ TGF- $\beta$ showed a significant increase in these cytokines. Administration of $\alpha$ EBI- 3 alone or in combination with $\alpha$ TGF- $\beta$ resulted in significant production of these proinflammatory cytokines (Figures 6A-C). Moreover, there was significant suppression of IL-4 and IL-10 responses along with TGF-beta and EBI-3 (Figures 6D-G). However, introduction of $\alpha$ EBI-3 along with $\alpha$ TGF- $\beta$ not only resulted in the maximum production of these immuno-protective cytokines but also led to inhibition of disease promoting IL-4 and IL-10. No significant alteration in IL-27 (p28) levels in the culture supernatants of various indicated groups of mice (Figure 6G) were found. The effect of combined neutralization of TGF$\beta$ and EBI-3 on signaling cascade was also investigated. Previous reports showed that Leishmania infection is associated with enhanced expression of Arginase 1 and diminished production of nitric oxide synthase thereby low generation of the key anti-leishmanial molecule nitric oxide (25). The expression of arginase 1 from the splenic cell lysates derived from mice treated with the neutralizing antibodies for EBI3 , TGF- $\beta$, and CD25, was found to be down regulated as compared to control IgG-treated (Figure S1A). Mice treated with $\alpha \mathrm{CD} 25$ only also showed a substantial reduction in arginase 1 expression compared to naive but the mice treated with $\alpha$ TGF- $\beta+\alpha$ EBI- 3 antibodies showed the best results with lowest expression of arginase 1 . The antagonistic effect of arginase 1 to inducible nitric oxide synthase (iNOS) was found with significant loss of iNOS expression in the $\alpha$ TGF- $\beta$ and $\alpha$ EBI-3 treated mice (Figure S1A). To investigate whether the reduction of arginase 1 and concurrent up regulation of iNOS is dependent on the STAT6 as reported by Osorio et al. during L. donovani infection (26) in vitro blocking of EBI3 in the culture of splenocytes of infected mice was assayed. Neutralization of EBI-3 of infected splenocytes resulted in down regulation in the expression of both STAT6 as well as arginase 1 (Figure S1B).

\section{Neutralization of EBI-3 Along With TGF- $\beta$ Limits Progression of $L$. donovani Infection in BALB/c Mice}

Since EBI-3 and TGF- $\beta$ suppressed the host protective anti-leishmanial response, the effects of EBI-3 and TGF- $\beta$ neutralization on disease progression in $\mathrm{BALB} / \mathrm{c}$ mice were studied. A significant fall in the parasite burden of spleen and liver in the all treatment groups was observed when compared to control (Figures 7B,C,E,F). However, the most effective protection was observed in mice treated with a combination of 


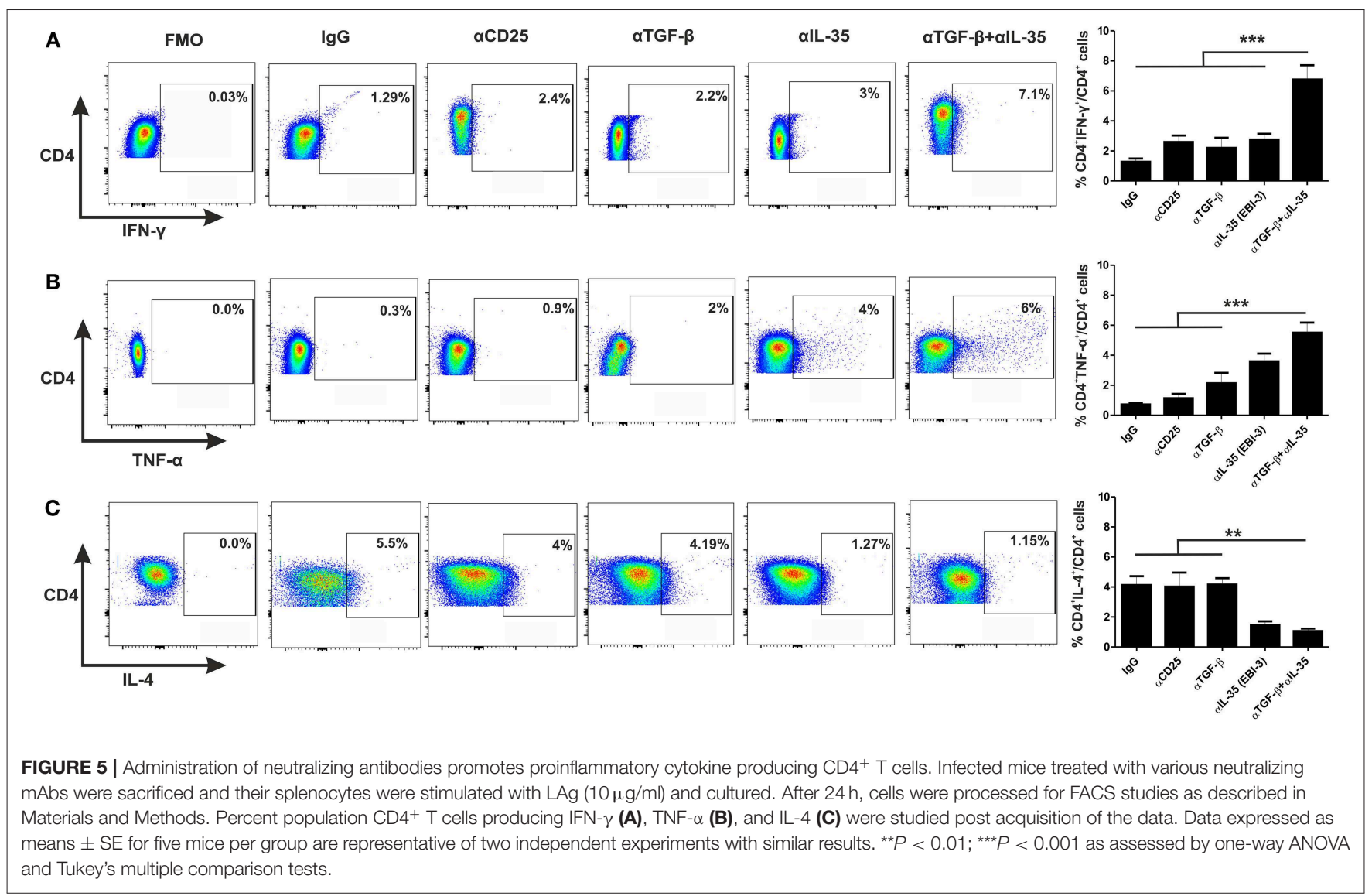

$\alpha$ TGF- $\beta+\alpha$ EBI- 3 mAbs. The reduction in parasite burden was concomitant to the resistance to hepato- and splenomegaly in the treatment groups (Figures 7A,D).

\section{DISCUSSION}

An impaired cellular immunity is a distinctive feature of active visceral leishmaniasis. Despite advances, the functional role of regulatory cells and their cytokines in suppression of antileishmanial immunity is not well elucidated. In this present study we have investigated the dynamicity of cellular and cytokine responses during experimental visceral leishmaniasis, and to determine the functional effects of the infection induced cytokines on progression of $L$. donovani infection in $\mathrm{BALB} / \mathrm{c}$ mice.

Chronic infection of $L$. donovani in the mammalian phagocytes results in adenopathy of liver and spleen with loss of cell mediated immune responsiveness (19, 27, 28). A clear understanding of the immunology of VL primarily suffers due to limitations of appropriate disease models for immunological studies. Previous studies on infection kinetics of L. donovani AG83 in BALB/c mice indicate that similar to natural infection the disease is chronically progressive peaking up to 16 weeks post challenge $(29,30)$. Therefore, the same infection model was selected for the present study. The kinetics of parasite burden post challenge indicates a steep increase in liver infection at 2 months compared to splenic infection. Possibly, a complex cellular organization of spleen (12) contributes to initial resistance as observed during several disease models of acute VL infection (31). The progression of infection is suggestive of an acute pre-established infection at 1 month, established infection following 2 months and a chronic phase post 3 months of challenge with virulent $L$. donovani in BALB/c mice. Therefore, for studies related to comparisons of immunomodulations at pre-established (1 month) and extensively chronic (4 months) of infection time points were evaluated. However, in vivo neutralization studies were performed at 3 months of optimum chronic phase of infection. It is noteworthy that at early infection there was an enhanced induction of pro-inflammatory cytokine response of TNF- $\alpha$ and IFN- $\gamma$, which gradually reduced to basal levels with the surge of regulatory cytokines, IL-4, IL-10, and TGF- $\beta$ in later infection. Studies on different subunit chains of IL-12 family revealed that p35 chain of IL-12 and EBI3 were gradually up regulated, while p28 of IL-27 and p40 of IL-12 remained restricted during the course of infection. IL-12 (p35) and EBI-3 constitute IL-35, a cytokine known for its immunosuppressive role in cancer and other chronic infectious diseases, but is crucial for deterrence of autoimmune complexities (32-34). Previous reports implicate the involvement of IL-10 and TGF- $\beta$ in restriction of the protective cytokine response in murine VL $(27,35,36)$. The roles of IL-35 in VL pathology alone or in combination with other regulatory 


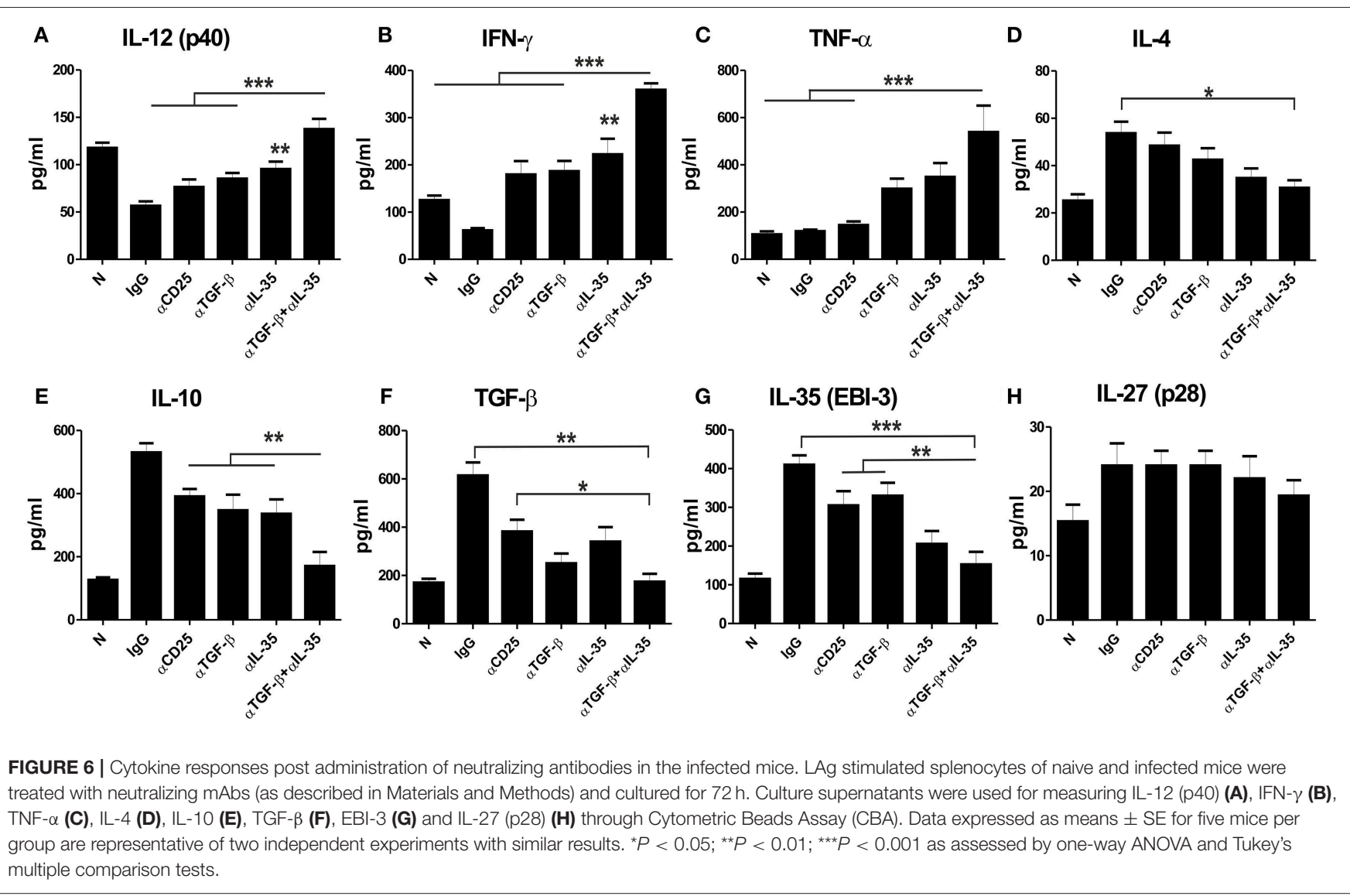

cytokines in immunomodulation have not been studied before. The surge in the levels of both the subunit chains of IL-35 in chronic L. donovani infection prompted an investigation on the cellular source and functional correlation of the cytokine. However, a major obstacle in the study of the fully functional IL35 is the issue of cross-reactivity with either IL-12 or with IL-27. To address the issue the functional studies were limited to a single subunit chain, EBI-3 with parallel comparison with p28 (IL-27).

Immuno-phenotypic characterization of splenic $\mathrm{T}$ cells demonstrated a significant surge in proportions of $\mathrm{CD} 4{ }^{+} \mathrm{CD} 25^{+}$ and $\mathrm{CD}^{+}{ }^{-} \mathrm{FoxP}^{+} \mathrm{T}$ accompanied with loss of cellular proliferative and proinflammatory cytokine response as chronic infection was established. Interestingly, at early infection a significant proportion of IFN- $\gamma$ and TNF- $\alpha$ producing cells predominantly from $\mathrm{CD} 4^{+} \mathrm{CD} 25^{-}$and $\mathrm{CD} 4^{+}$FoxP3 ${ }^{-}$T cell were observed. However, with progression of infection the level of the proinflammatory cytokine producing cell populations were significantly reduced. The observations were in consistence to previous reports of anti-leishmanial response at acute phase of infection gradually progressing to $\mathrm{T}$ cell anergic state in chronic VL $(37,38)$. The drop in IFN- $\gamma$ and TNF- $\alpha$ producing cells at chronic infection were accompanied with surge in the IL10 , TGF- $\beta$ and EBI-3 producing CD4 ${ }^{+} \mathrm{T}$ cells. The functional association of cytokine response was analyzed by a combination of neutralization of IL-27 (p28), IL-10, TGF- $\beta$, and EBI-3 in vitro in the co-cultures of enriched $\mathrm{CD} 4{ }^{+} \mathrm{CD} 25^{+}$on $\mathrm{CD} 4{ }^{+} \mathrm{CD} 25^{-}$ cells. Restoration of the effector functions and proliferation of co-cultured $\mathrm{T}$ cells following neutralization of IL-10, TGF- $\beta$ and EBI-3 revealed the immuno-suppressive effect of the cytokines. IL-10 and TGF- $\beta$ producing $\mathrm{CD}^{+}{ }^{+} \mathrm{T}$ cell have been previously reported to dampen host inflammatory responses and to be involved in the pathogenesis of $L$. donovani infection $(11,12$, $39,40)$. In consistence with previous reports of induction of Th1 type immune response following IL-10 neutralization (41, 42), similar immunomodulatory effects were found in the ex vivo experiments. Our study extended the findings with EBI-3. Moreover, combined neutralization of TGF- $\beta$ and EBI- 3 resulted in the most effective restoration of proliferation and IFN- $\gamma$ and TNF- $\alpha$ response. Unaltered immuno-repressed milieu post IL-27 (p28) blocking, either alone or in combination, indicated that IL27 (p28) may not have a role in suppression of anti-leishmanial immunity. Therefore, it appears that EBI-3 dominantly from IL-35 plays a crucial role in immune suppression.

Earlier studies reported that IL-35, similar to IL-10, to be crucial for suppressing inflammatory responses during auto-immunity and cancer $(13,43,44)$. Therapy with IL35 during collagen-induced arthritis helped in the expansion of Tregs (45). During viral infection, targeting EBI-3 led to cure (14). The suppressive activities of IL-10 $(46,47)$ and TGF- $\beta$ (48-50) and their contribution in murine VL are well established (51). Subsequently, Murray and colleagues proposed targeting IL-10 by neutralizing antibodies as a promising immunotherapy against murine VL $(22,46)$. To ascertain whether blocking the effect of TGF- $\beta$ and EBI-3 in vivo 

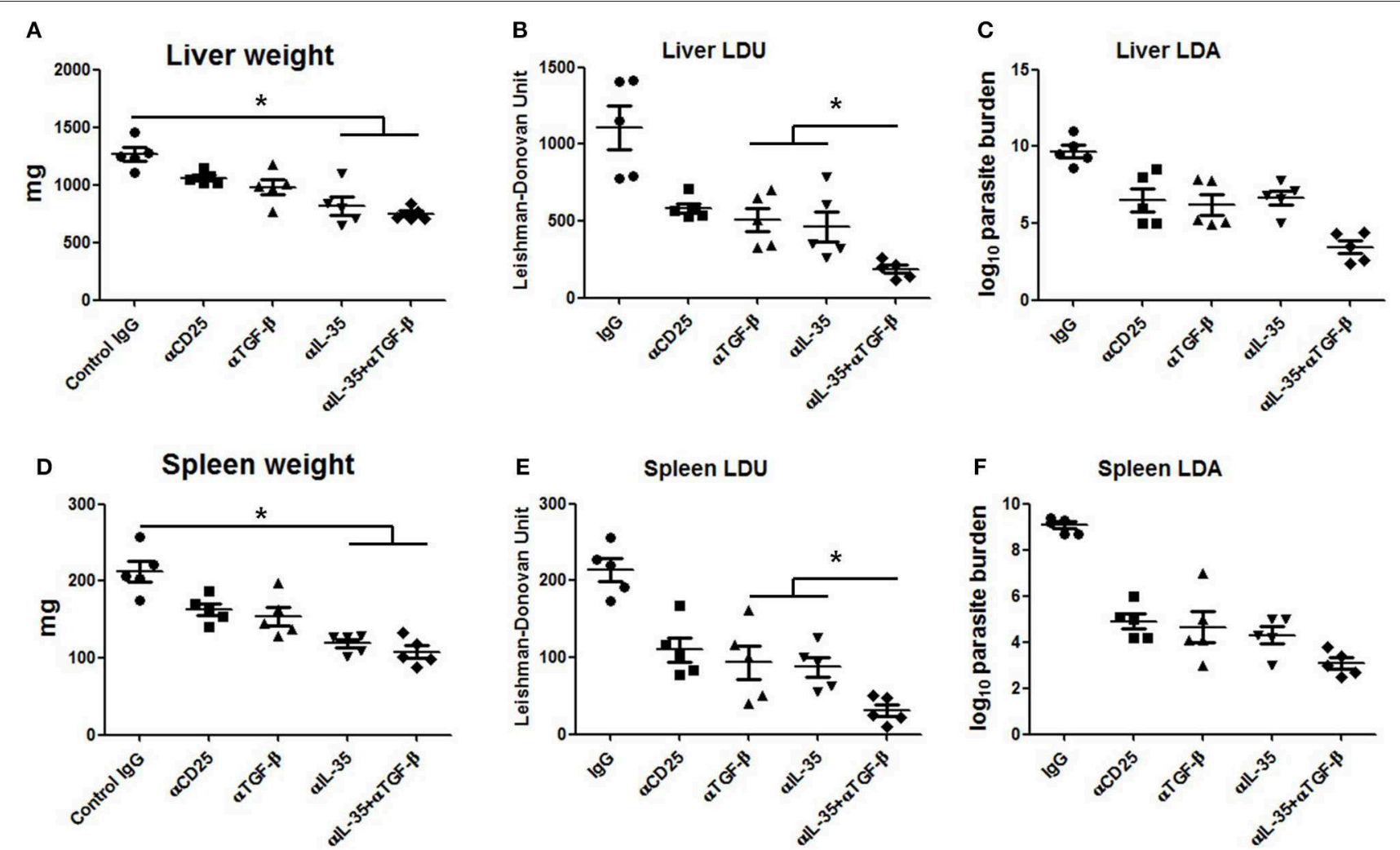

FIGURE 7 | Parasite burden in neutralizing antibody treated infected mice. Infected BALB/c mice injected with $200 \mu \mathrm{g}$ of neutralizing antibodies against TGF- $\beta$, IL-35, $\mathrm{CD} 25$, and isotype control (IgG cocktail) into the peritoneal cavity (as described in Materials and Methods) were sacrificed after 3 months of infection for measuring parasite burden in the liver and spleen. Total organ weights of liver and spleen (A,D) as well as their parasite burden were determined by LDU (B,E) and LDA (C,F). Data expressed as means \pm SE for five mice per group are representative of two independent experiments with similar results. ${ }^{*} P<0.05$ as assessed by one-way ANOVA and Tukey's multiple comparison tests.

can similarly resist Leishmania infection induced immune suppression, immunomodulatory effect and parasite burden of infected $\mathrm{BALB} / \mathrm{c}$ mice treated with combinations of $\alpha$-TGF- $\beta$ and $\alpha$-EBI- 3 were evaluated. The in vivo neutralization led to significant increase in IL-12 (p40) and IFN- $\gamma$ production post EBI-3 blocking along with a reversal in immune suppressed milieu by simultaneous neutralization of TGF- $\beta$ and EBI3 in infected mice. Blocking of these cytokines not only enhanced the pro-inflammatory cytokines but also increased the IFN- $\gamma$ and TNF- $\alpha$ producing $\mathrm{CD}^{+} \mathrm{T}$ cells. Moreover, whereas, single neutralization of TGF- $\beta$ or EBI-3 helped in partial resistance to the infection, their combined neutralization led to $\sim 5$-fold reduction in parasite load in both liver and spleen.

The resistance to parasite burden was also associated with a down regulation of arginase 1 expression, along with enhanced nitric oxide production. Suppression of arginase 1, an inhibitor of nitric oxide production (24) may result in NO mediated parasite killing. Moreover, this reduction of arginase 1 level was dependent on the expression of STAT6, which indicates that EBI-3 promotes $L$. donovani mediated arginase 1 expression in STAT6 dependent manner to down regulate NO production. Our studies, therefore, propose that
EBI-3 is crucial for immunosuppression in VL. Moreover, EBI-3 together with TGF- $\beta$ is the major contributor to the immunologically subverted milieu conducive for parasite survival and immune evasion.

\section{CONCLUSION}

Progressive L. donovani infection in BALB/c mice results in gradual up regulation of IL-10, TGF- $\beta$ and both the subunit chains of IL-35. The loss in proinflammatory response during chronic VL is accompanied by accumulation of $\mathrm{CD}^{+}{ }^{+} \mathrm{CD} 25^{+}$and $\mathrm{CD}^{+}{ }^{+} \mathrm{FoxP}^{+} \mathrm{T}$ cells with TGF$\beta$ and IL-35 (EBI-3) as the key factors for subversion of anti-leishmanial immunity. A more detailed study on the role of IL-35 and the subunit chains of IL-12 family may open new insights in understanding the hostpathogen immunology that can potentially generate novel immunotherapeutic approaches.

\section{ETHICS STATEMENT}

The studies were performed according to the Committee for the Purpose of Control and Supervision on Experimental 
Animals (CPCSEA), Ministry of Environment and Forest, Govt. of India, and approved by the Animal Ethics Committee (147/1999/CPSCEA) of Indian Institute of Chemical Biology.

\section{AUTHOR CONTRIBUTIONS}

MA and NA: conceptualization. MA, NA, AS, and MS: methodology. MA, MS, AS, MK, SD, and ND: investigation. MA, AS, and NA: writing-original draft. MA, MS, AS, MK, and NA: writing - review and editing. NA: funding acquisition, resources, and supervision.

\section{FUNDING}

This work has been supported by Council of Scientific and Industrial Research-BSC 0114, Indian Council of Medical Research and University Grant Commission, Government of India.

\section{REFERENCES}

1. Visperas A, Vignali DA. Are regulatory $T$ cells defective in type 1 diabetes and can we fix them? J Immunol. (2016) 197:3762-70. doi: 10.4049/jimmunol.1601118

2. Toulza F, Tsang L, Ottenhoff TH, Brown M, Dockrell HM. Mycobacterium tuberculosis-specific CD4+ T-cell response is increased, and Treg cells decreased, in anthelmintic-treated patients with latent TB. Eur J Immunol. (2016) 46:752-61. doi: 10.1002/eji.201545843

3. Miles B, Miller SM, Folkvord JM, Levy DN, Rakasz EG, Skinner PJ, et al. Follicular regulatory CD8 T cells impair the germinal center response in SIV and ex vivo HIV infection. PLoS Pathog. (2016) 12:e1005924. doi: 10.1371/journal.ppat.1005924

4. Hasanjani Roushan MR, Bayani M, Soleimani Amiri S, MohammadniaAfrouzi M, Nouri HR, Ebrahimpour S. Evaluation of CD4 ${ }^{+} \mathrm{CD}_{2} 5^{+} \mathrm{FoxP}^{+}$ regulatory $\mathrm{T}$ cells during treatment of patients with brucellosis. J Biol Regul Homeost Agents. (2016) 30:675-82. Available online at: https://europepmc. org/abstract/med/27655484

5. Arvey A, van der Veeken J, Samstein RM, Feng Y, Stamatoyannopoulos JA, Rudensky AY. Inflammation-induced repression of chromatin bound by the transcription factor Foxp3 in regulatory T cells. Nat Immunol. (2014) 15:580-7. doi: $10.1038 /$ ni.2868

6. Chaudhry A, Rudensky AY. Control of inflammation by integration of environmental cues by regulatory T cells. J Clin Invest. (2013) 123:939-44. doi: 10.1172/JCI57175

7. Shadab M, Jha B, Asad M, Deepthi M, Kamran M, Ali N. Apoptosislike cell death in Leishmania donovani treated with KalsomeTM10, a new liposomal amphotericin B. PLoS ONE. (2017) 12:e0171306. doi: 10.1371/journal.pone.0171306

8. Ejazi SA, Bhattacharya P, Bakhteyar MA, Mumtaz AA, Pandey K, Das $\mathrm{VN}$, et al. Noninvasive diagnosis of visceral leishmaniasis: development and evaluation of two urine-based immunoassays for detection of leishmania donovani infection in India. PLoS Negl Trop Dis. (2016) 10:e0005035. doi: 10.1371/journal.pntd.0005035

9. Rodrigues V, Cordeiro-da-Silva A, Laforge M, Silvestre R, Estaquier J. Regulation of immunity during visceral Leishmania infection. Parasit Vectors. (2016) 9:118. doi: 10.1186/s13071-016-1412-x

10. Sabur A, Bhowmick S, Chhajer R, Ejazi SA, Didwania N, Asad M, et al. Liposomal elongation factor-1alpha triggers effector CD4 and $\mathrm{CD} 8 \mathrm{~T}$ cells for induction of long-lasting protective immunity against visceral leishmaniasis. Front Immunol. (2018) 9:18. doi: 10.3389/fimmu.2018. 00018

\section{ACKNOWLEDGMENTS}

The authors thank Dr. Mithun Maji and Dr. Pradyot Bhattacharya for valuable suggestions and Ms. Debalina chakraborty, Mr. Mudasir Ahmad Malik, Ms. Varsha Srinivasan, Ms. Varsha Gupta, Ms. Ananyashree Behara, and Ms. Shilpa Sen for helping in performing experiments. The authors would also like to thank Mr. Tanmoy Dalui and Dr. Sumanta Basu for flow cytometry based studies and Mr. Janmejay Midya for animal studies. This work has been supported by Council of Scientific and Industrial Research, J.C. Bose National Fellowship, DST, Indian Council of Medical Research and University Grant Commission, Government of India.

\section{SUPPLEMENTARY MATERIAL}

The Supplementary Material for this article can be found online at: https://www.frontiersin.org/articles/10.3389/fimmu. 2019.00616/full\#supplementary-material

11. Bhattacharya P, Ghosh S, Ejazi SA, Rahaman M, Pandey K, Ravi Das $\mathrm{VN}$, et al. Induction of IL-10 and TGFbeta from CD4+CD25+FoxP3+ $\mathrm{T}$ cells correlates with parasite load in indian kala-azar patients infected with leishmania donovani. PLoS Negl Trop Dis. (2016) 10:e0004422. doi: 10.1371/journal.pntd.0004422

12. Montes de Oca M, Kumar R, de Labastida Rivera F, Amante FH, Sheel M, Faleiro RJ, et al. Blimp-1-dependent IL-10 production by $\operatorname{Tr} 1$ cells regulates TNF-mediated tissue pathology. PLoS Pathog. (2016) 12:e1005398. doi: 10.1371/journal.ppat.1005398

13. Collison LW, Chaturvedi V, Henderson AL, Giacomin PR, Guy C, Bankoti J, et al. IL-35-mediated induction of a potent regulatory T cell population. Nat Immunol. (2010) 11:1093-101. doi: 10.1038/ni.1952

14. Xiang XG, Xie Q. IL-35: a potential therapeutic target for controlling hepatitis B virus infection. J Dig Dis. (2015) 16:1-6. doi: 10.1111/1751-2980.12218

15. Vignali DA, Kuchroo VK. IL-12 family cytokines: immunological playmakers. Nat Immunol. (2012) 13:722-8. doi: 10.1038/ni.2366

16. Afrin F, Ali N. Adjuvanticity and protective immunity elicited by Leishmania donovani antigens encapsulated in positively charged liposomes. Infect Immun. (1997) 65:2371-7.

17. de Morais-Teixeira E, Aguiar MG, Soares de Souza Lima B, Ferreira LA, Rabello A. Combined suboptimal schedules of topical paromomycin, meglumine antimoniate and miltefosine to treat experimental infection caused by Leishmania (Viannia) braziliensis. J Antimicrob Chemother. (2015) 70:3283-90. doi: 10.1093/jac/dkv254

18. Pereira JC, Ramos TD, Silva JD, de Mello MF, Pratti JES, da Fonseca-Martins $\mathrm{AM}$, et al. Effects of bone marrow mesenchymal stromal cell therapy in experimental cutaneous leishmaniasis in $\mathrm{BALB} / \mathrm{c}$ mice induced by Leishmania amazonensis. Front Immunol. (2017) 8:893. doi: 10.3389/fimmu.2017. 00893

19. Banerjee A, De M, Ali N. Complete cure of experimental visceral leishmaniasis with amphotericin B in stearylamine-bearing cationic liposomes involves down-regulation of IL-10 and favorable T cell responses. J Immunol. (2008) 181:1386-98. doi: 10.4049/jimmunol.181.2.1386

20. Asad M, Bhattacharya P, Banerjee A, Ali N. Therapeutic and immunomodulatory activities of short-course treatment of murine visceral leishmaniasis with KALSOME10, a new liposomal amphotericin B. BMC Infect Dis. (2015) 15:188. doi: 10.1186/s12879-015-0928-6

21. Lin J, Li M, Wang Z, He S, Ma X, Li D. The role of CD4+CD25+ regulatory T cells in macrophage-derived foam-cell formation. J Lipid Res. (2010) 51:120817. doi: 10.1194/jlr.D000497

22. Murray HW, Lu CM, Mauze S, Freeman S, Moreira AL, Kaplan G, et al. Interleukin-10 (IL-10) in experimental visceral leishmaniasis and IL-10 
receptor blockade as immunotherapy. Infect Immun. (2002) 70:6284-93. doi: 10.1128/IAI.70.11.6284-6293.2002

23. Stanley AC, Zhou Y, Amante FH, Randall LM, Haque A, Pellicci DG, et al. Activation of invariant NKT cells exacerbates experimental visceral leishmaniasis. PLoS Pathog. (2008) 4:e1000028. doi: 10.1371/journal.ppat.1000028

24. Osorio EY, Zhao W, Espitia C, Saldarriaga O, Hawel L, Byus CV, et al. Progressive visceral leishmaniasis is driven by dominant parasiteinduced STAT6 activation and STAT6-dependent host arginase 1 expression. PLoS Pathog. (2012) 8:e1002417. doi: 10.1371/journal.ppat. 1002417

25. Soong L, Henard CA, Melby PC. Immunopathogenesis of non-healing American cutaneous leishmaniasis and progressive visceral leishmaniasis. Semin Immunopathol. (2012) 34:735-51. doi: 10.1007/s00281-0120350-8

26. Osorio EY, Travi BL, da Cruz AM, Saldarriaga OA, Medina AA, Melby PC. Growth factor and Th2 cytokine signaling pathways converge at STAT6 to promote arginase expression in progressive experimental visceral leishmaniasis. PLoS Pathog. (2014) 10:e1004165. doi: 10.1371/journal.ppat.1004165

27. Owens BM, Beattie L, Moore JW, Brown N, Mann JL, Dalton JE, et al. IL10-producing Th1 cells and disease progression are regulated by distinct CD11c(+) cell populations during visceral leishmaniasis. PLoS Pathog. (2012) 8:e1002827. doi: 10.1371/journal.ppat.1002827

28. Moore JW, Beattie L, Osman M, Owens BM, Brown N, Dalton JE, et al. $\mathrm{CD} 4+$ recent thymic emigrants are recruited into granulomas during leishmania donovani infection but have limited capacity for cytokine production. PLOS ONE. (2016) 11:e0163604. doi: 10.1371/journal.pone. 0163604

29. Mukhopadhyay S, Bhattacharyya S, Majhi R, De T, Naskar K, Majumdar S, et al. Use of an attenuated leishmanial parasite as an immunoprophylactic and immunotherapeutic agent against murine visceral leishmaniasis. Clin Diagn Lab Immunol. (2000) 7:233-40. doi: 10.1128/CDLI.7.2.233-240.2000

30. Ravindran R, Bhowmick S, Das A, Ali N. Comparison of BCG, MPL and cationic liposome adjuvant systems in leishmanial antigen vaccine formulations against murine visceral leishmaniasis. BMC Microbiol. (2010) 10:181. doi: 10.1186/1471-2180-10-181

31. Tsagozis P, Karagouni E, Dotsika E. Function of CD8+ T lymphocytes in a selfcuring mouse model of visceral leishmaniasis. Parasitol Int. (2005) 54:139-46. doi: 10.1016/j.parint.2005.02.005

32. Wang Z, Liu JQ, Liu Z, Shen R, Zhang G, Xu J, et al. Tumorderived IL-35 promotes tumor growth by enhancing myeloid cell accumulation and angiogenesis. J Immunol. (2013) 190:2415-23. doi: 10.4049/jimmunol.1202535

33. Teymouri M, Pirro M, Fallarino F, Gargaro M, Sahebkar A. IL35 , a hallmark of immune-regulation in cancer progression, chronic infections and inflammatory diseases. Int J Cancer. (2018) 143:2105-15. doi: $10.1002 /$ ijc.31382

34. Su LC, Liu XY, Huang AF, Xu WD. Emerging role of IL-35 in inflammatory autoimmune diseases. Autoimmun Rev. (2018) 17:665-73. doi: 10.1016/j.autrev.2018.01.017

35. Anderson CF, Lira R, Kamhawi S, Belkaid Y, Wynn TA, Sacks D. IL10 and TGF-beta control the establishment of persistent and transmissible infections produced by Leishmania tropica in C57BL/6 mice. J Immunol. (2008) 180:4090-7. doi: 10.4049/jimmunol.180.6.4090

36. Wilson ME, Recker TJ, Rodriguez NE, Young BM, Burnell KK, Streit JA, et al. The TGF-beta response to Leishmania chagasi in the absence of IL-12. Eur J Immunol. (2002) 32:3556-65. doi: 10.1002/15214141(200212)32:12<3556::AID-IMMU3556>3.0.CO;2-Q

37. Nylen S, Sacks D. Interleukin-10 and the pathogenesis of human visceral leishmaniasis. Trends Immunol. (2007) 28:378-84. doi: 10.1016/j.it.2007.07.004
38. Rodrigues V, Cordeiro-da-Silva A, Laforge M, Ouaissi A, Akharid K, Silvestre $\mathrm{R}$, et al. Impairment of T cell function in parasitic infections. PLoS Negl Trop Dis. (2014) 8:e2567. doi: 10.1371/journal.pntd.0002567

39. Hammami A, Abidin BM, Heinonen KM, Stager S. HIF-1alpha hampers dendritic cell function and Th1 generation during chronic visceral leishmaniasis. Sci Rep. (2018) 8:3500. doi: 10.1038/s41598-018-21891-z

40. Kumar V, Tiwari N, Gedda MR, Haque R, Singh RK. Leishmania donovani infection activates Toll-like receptor 2, 4 expressions and Transforming growth factor-beta mediated apoptosis in renal tissues. Braz J Infect Dis. (2017) 21:545-9. doi: 10.1016/j.bjid.2017.04.007

41. Faleiro RJ, Kumar R, Bunn PT, Singh N, Chauhan SB, Sheel M, et al. Combined immune therapy for the treatment of visceral leishmaniasis. PLoS Negl Trop Dis. (2016) 10:e0004415. doi: 10.1371/journal.pntd.0004415

42. Bhattacharjee S, Gupta G, Bhattacharya P, Adhikari A, Majumdar SB, Majumdar S. Anti-iL-10 mAb protection against experimental visceral leishmaniasis via induction of Th1 cytokines and nitric oxide. Indian J Exp Biol. (2009) 47:489-97. Available online at: http://nopr.niscair.res.in/handle/ $123456789 / 4375$

43. Dambuza IM, He C, Choi JK, Yu CR, Wang R, Mattapallil MJ, et al. IL-12p35 induces expansion of IL-10 and IL-35-expressing regulatory B cells and ameliorates autoimmune disease. Nat Commun. (2017) 8:719. doi: 10.1038/s41467-017-00838-4

44. Turnis ME, Sawant DV, Szymczak-Workman AL, Andrews LP, Delgoffe GM, Yano H, et al. Interleukin-35 limits anti-tumor immunity. Immunity. (2016) 44:316-29. doi: 10.1016/j.immuni.2016.01.013

45. Niedbala W, Wei XQ, Cai B, Hueber AJ, Leung BP, McInnes IB, et al. IL-35 is a novel cytokine with therapeutic effects against collagen-induced arthritis through the expansion of regulatory T cells and suppression of Th17 cells. Eur J Immunol. (2007) 37:3021-9. doi: 10.1002/eji.200737810

46. Murray HW, Flanders KC, Donaldson DD, Sypek JP, Gotwals PJ, Liu J, et al. Antagonizing deactivating cytokines to enhance host defense and chemotherapy in experimental visceral leishmaniasis. Infect Immun. (2005) 73:3903-11. doi: 10.1128/IAI.73.7.3903-3911.2005

47. Murray HW, Zhang Y, Raman VS, Reed SG, Ma X. Regulatory actions of Tolllike receptor 2 (TLR2) and TLR4 in Leishmania donovani infection in the liver. Infect Immun. (2013) 81:2318-26. doi: 10.1128/IAI.01468-12

48. Chowdhury BP, Das S, Majumder S, Halder K, Ghosh S, Biswas S, et al. Immunomodulation of host-protective immune response by regulating Foxp3 expression and Treg function in Leishmania-infected BALB/c mice: critical role of IRF1. Pathog Dis. (2015) 73:ftv063. doi: 10.1093/femspd/ftv063

49. Bhowmick S, Mazumdar T, Ali N. Vaccination route that induces transforming growth factor beta production fails to elicit protective immunity against Leishmania donovani infection. Infect Immun. (2009) 77:1514-23. doi: 10.1128/IAI.01739-07

50. Rodrigues V Jr, Santana da Silva J, Campos-Neto A. Transforming growth factor beta and immunosuppression in experimental visceral leishmaniasis. Infect Immun. (1998) 66:1233-6.

51. Asad M, Ali N. Dynamicity of immune regulation during visceral leishmaniasis. Proc Indian Natl Sci Acad. (2014) 80:247-67. doi: $10.16943 /$ ptinsa/2014/v80i2/55105

Conflict of Interest Statement: The authors declare that the research was conducted in the absence of any commercial or financial relationships that could be construed as a potential conflict of interest.

Copyright (๑) 2019 Asad, Sabur, Shadab, Das, Kamran, Didwania and Ali. This is an open-access article distributed under the terms of the Creative Commons Attribution License (CC BY). The use, distribution or reproduction in other forums is permitted, provided the original author(s) and the copyright owner(s) are credited and that the original publication in this journal is cited, in accordance with accepted academic practice. No use, distribution or reproduction is permitted which does not comply with these terms. 